\title{
Famílias em situação plurilíngue: ideologias linguísticas
}

\author{
Karen Pupp Spinasséa \\ Isabella Mozzillo ${ }^{b}$
}

\begin{abstract}
Resumo
As famílias linguisticamente mistas possuem um acordo, tácito ou explícito, que constitui a política linguistica familiar (KING; LOGAN-TERRY, 2008; MOZZILLO; PUPP SPINASSÉ, 2020) e define as práticas cotidianas, bem como o projeto de transmissão e de manutenção (ou não) das línguas. Quando a(s) lingua(s) do lar não coincide(m) com a(s) do mundo exterior, pode haver uma situação de confronto entre o que é minoritário e o que é majoritário. A forma como a família vai lidar com o plurilinguismoé, com frequência, uma escolha pautada não necessariamente em uma decisão consciente ou esclarecida, mas é, em grande parte, influenciada por ideologias linguísticas (WOOLARD, 2007) - as quais nem sempre estão de acordo com o que apontam resultados de estudos da área já que essas ideologias estão constantemente imbuídas de crenças (PAJARES, 1992). Assim, dependendo das práticas adotadas, a família pode determinar e fomentar o bilinguismo das crianças ou pode mesmo impedir que os filhos sejam criados com mais de uma lingua, levando ao monolinguismo. Nesse sentido, o presente artigo pretende abordar algumas ideologias linguísticas obtidas do discurso de pais e mães de famílias em situação plurilíngue, apresentando os ideologemas encontrados.
\end{abstract}

Palavras-chave: Ideologias linguísticas. Famílias plurilingues. Bilinguismo familiar.

Recebido em: 29/09/2020 Aceito em: 20/11/2020

\footnotetext{
${ }^{a}$ Universidade Federal do Rio Grande do Sul, Instituto de Letras, Departamento de Línguas Modernas, Porto Alegre, RS, Brasil. E-mail: spinasse@ufrgs.br

b Universidade Federal de Pelotas, Centro de Letras e Comunicação, Pelotas, RS, Brasil.

E-mail: isabellamozzillo@gmail.com
}

\section{Como citar:}

Mozzillo, I.; Spinassé, K. P. Famílias em situação plurilíngue: ideologias linguísticas. Gragoatá, 
${ }^{1}$ Usaremos os termos bilinguismo e plurilinguismo sem distinção, seguindo Mackey (2013, p. 708), em único contraponto ao termo monolinguismo, já que a diferença do número de línguas utilizadas pelos participantes (se é mais de uma ou mais de duas) não é importante neste trabalho. Contudo, apoiando-nos na Carta Europeia do Plurilinguismo (OBSERVATÓRIO, 2010) e entendendo, por conseguinte, bi/ plurilinguismo como o uso que determinado indivíduo faz de uma ou mais línguas, diferenciaremos estes do conceito "multilinguismo", caracterizado, pelo mesmo documento, como "a coexistência de várias línguas num grupo social" (p. 1). Assim, enquanto bi/plurilinguismo se refere ao

âmbito individual, multilinguismo irá remeter a um ambiente (sociedade, território, comunidade, espaço, núcleo...) onde línguas coexistem.

\footnotetext{
${ }^{2}$ Como algumas famílias ou membros das famílias não exercem (mais) esse plurilinguismo, mesmo que o contexto seja multilíngue ou que o histórico familiar seja plurilíngue, em vez de denominá-las "famílias plurilíngues" optamos por utilizar a expressão mais abrangente "famílias em situação plurilíngue".
}

\section{Introdução}

Considerando a mobilidade de indivíduos e de grupos pelo mundo, é muito comum a existência de famílias mistas (DEPREZ; VARRO; COLLET, 2014, p. 8). Essa diversidade pode dever-se a múltiplos fatores, como diferentes nacionalidades, culturas, etnias e/ou religiões dos membros que constituem essas famílias. Além disso, muitas vezes, também as línguas podem ser distintas.

Nesse escopo, existem, por exemplo, famílias plurilíngues ${ }^{1}$ (ou famílias em situação plurilíngue ${ }^{2}$ ), as quais, por sua vez, podemos subdividir em três tipos: 1) aquelas cujos membros possuem línguas maternas distintas, utilizando-as, de alguma forma, no âmbito familiar; 2) aquelas resultantes de uma mobilidade internacional, levando a mudança de território à configuração familiar linguística mista; e 3) aquelas que, saindo ou não de seus territórios, utilizam, no lar, por diferentes motivos, uma língua que não é uma língua materna familiar e que também é diferente da(s) praticada(s) no entorno.

Em resumo, famílias podem ser mistas e monolíngues, mas, no contexto de famílias em situação plurilíngue, como as mencionadas anteriormente, podemos ter a configuração "não mistas e plurilíngues" ou "mistas e plurilíngues ao mesmo tempo" (DEPREZ; VARRO; COLLET, 2014, p. 8).

Entretanto, a forma como as línguas coabitam e expressam as relações conjugais e familiares não é homogênea e depende das ideologias linguísticas presentes no espaço doméstico e no espaço externo. Para tanto, sempre existe um acordo, tácito ou explícito, nas famílias linguisticamente mistas a respeito das práticas cotidianas e das intenções (positivas ou negativas) em relação à transmissão e à manutenção das línguas. Os aspectos envolvidos nesse acordo constituem o que denominamos "política linguística familiar" (KING; LOGAN-TERRY, 2008, p. 6; MOZZILLO; PUPP SPINASSÉ, 2020, p. 1309).

Quando a(s) língua(s) do lar não coincide(m) com a(s) do meio exterior, pode surgir ainda uma situação de confronto entre o que é minoritário e o que é majoritário, e a coexistência dessas variedades exige de seus falantes atitudes perante a situação. Essas atitudes, por sua vez, dependem das crenças que esses falantes possuem em relação a tudo o que envolve o domínio das línguas em questão. Muitas vezes, por exemplo, 
uma língua familiar é deixada de lado e passa-se ao uso exclusivo da língua majoritária do lugar no qual a família está instalada. No entanto, isso não se dá necessariamente por uma decisão consciente, mas, muito constantemente, em função de ideologias linguísticas, as quais costumam estar sob influência de mitos e concepções já arraigados no imaginário do senso comum. Embora esses mitos já tenham sido contrariados por estudos científicos (GROSJEAN, 1982; 1995; OLIVEIRA, 2002; BAKER, 2014), eles continuam influenciando, como pudemos observar no âmbito de nosso projeto de pesquisa "Políticas linguísticas familiares - ideologias subjacentes", desenvolvido na Universidade Federal do Rio Grande do Sul.

Neste artigo, abordaremos as ideologias linguísticas familiares, apresentando alguns resultados de nossa pesquisa e alguns ideologemas presentes no discurso de membros de famílias em situação plurilíngue. Ao analisar as políticas linguísticas que vêm sendo praticadas em ambiente familiar e as ideologias subjacentes a elas, queremos refletir sobre a situação do plurilinguismo familiar de forma geral.

\section{Bilinguismo e políticas linguísticas}

Entendemos bilinguismo/plurilinguismo, conforme Mozzillo e Pupp Spinassé (2020, p. 1300), como a habilidade de conseguir "gerenciar (falar e/ou entender) duas ou mais línguas, utilizando cada uma para os respectivos contextos e propósitos necessários, com a propriedade necessária".

Inúmeros estudos já trataram das vantagens que "ser bilíngue" traz para o indivíduo, tanto do ponto de vista neurológico, como do ponto de vista social, linguístico e afetivo (GROSJEAN, 1982; 1995; HAKUTA, 1986; HAMERS; BLANC, 1989). Em famílias linguisticamente mistas, a oportunidade de tornar-se bilíngue já é dada desde cedo, em um processo natural de aquisição (ELLIS, 2008, p. 214). Contudo, por exemplo, quando a língua familiar é abandonada em prol da língua majoritária local, retira-se dos filhos essa possibilidade. Assim, muitas pessoas não se desempenham como bilíngues ou plurilíngues por causa de atitudes e decisões da família durante a infância e juventude, retardando o seu bilinguismo ou levando-as a uma situação de monolinguismo. Isso ocorre, muitas vezes, por falta de informação dos pais - ou por 
informações deturpadas acerca do bilinguismo (PEARSON, 2008).

No Brasil, a política linguística existente na sociedade tende a fortalecer a ideia do monolinguismo (OLIVEIRA, 2002), o que constitui mais um fator que pode levar pais a não "bilinguarem" (MOZZILLO; PUPP SPINASSÉ, 2020, p. 1302) os filhos. Quando não se promove socialmente a ideia positiva de se falar precocemente mais de uma língua, independentemente de seu status, é mais difícil que os pais se conscientizem de criar seus filhos de forma não monolíngue.

Ser bilíngue, contudo, pode ser visto como uma tendência mundial (PUPP SPINASSÉ, 2017, p. 223). Romaine (1997, p. 183-185) aponta seis tipos de aquisição bilíngue da linguagem por parte da criança: 1) Uma pessoa - uma língua: os pais têm línguas maternas diferentes, sendo que cada um possui certo grau de competência na língua do outro. A língua de um deles é também a língua dominante da comunidade. Cada um, porém, fala sua própria língua com a criança desde o nascimento; 2 ) Língua não dominante em casa/Uma língua - Um ambiente: os pais têm diferentes línguas maternas, e a língua de um deles é também a língua dominante da comunidade. Entretanto, ambos falam a língua não dominante com a criança, sendo a exposição à língua dominante restrita aos ambientes fora de casa, como, por exemplo, a escola; 3) Língua não dominante em casa sem apoio da comunidade: os pais têm a mesma língua materna, mas a língua dominante da comunidade é uma outra. Os dois falam a sua língua com a criança; 4) Duas línguas não dominantes em casa sem o apoio da comunidade: os pais têm línguas maternas diferentes, sendo que a língua dominante da comunidade não coincide com nenhuma delas. Cada um dos pais fala sua língua específica com a criança desde o nascimento; 5) Pais não nativos: os pais têm a mesma língua materna, e a língua dominante da comunidade é a mesma. Um dos pais, entretanto, sempre se dirige ao filho em uma língua que não é sua língua materna; 6) Línguas misturadas: os pais são bilíngues e setores da comunidade também o são. Os pais realizam alternância e mistura das línguas disponíveis.

Entre os participantes de nossa pesquisa, pudemos encontrar representantes de todos esses tipos, como veremos na seção da análise dos dados. No entanto, segundo Romaine (1997, p. 187), há diversos fatores individuais que afetam cada 
caso e os resultados obtidos: o tipo de exposição à língua minoritária, a consistência dos pais com a escolha linguística, as atitudes em relação ao bilinguismo por parte dos pais e das crianças, bem como as personalidades de todos eles. Se, por um lado, é interessante observar que há várias formas de se tornar bilíngue, independentemente da configuração familiar e/ou social, por outro lado, também é importante lembrar que há fatores que dificultam esse processo.

As atitudes negativas que prejudicam o desenvolvimento natural do bilinguismo derivam, muitas vezes, de dilemas ligados 1) ao prestígio das línguas na sociedade; 2) à forma como cada língua é vista por pais, familiares e comunidade; 3) à atitude dos pais em relação ao processo de bilinguar; 4) à possibilidade de mais interlocução na língua familiar e 5) ao peso afetivo das línguas no lar e no grupo social. Assim, as atitudes gerais em relação ao bilinguismo são determinadas pela família, mas em conjunto com as ideologias que circulam na sociedade.

Por isso, é interessante se pensar também no conceito de crenças, pois estas se fixam no senso comum, influenciando a forma de agir e a conduta das pessoas que as compartilham, conforme argumentou o filósofo Charles Sanders Peirce em seu ensaio sobre o pragmatismo intitulado "The Fixation of Belief", de 1877. As crenças seriam "ideias que se estabelecem na mente das pessoas como hábitos, costumes, tradições, meios populares de pensamento" (PEIRCE, 1958/1966, n. p.). Elas podem ser conscientes ou inconscientes, e trazem consigo um componente cognitivo, um componente afetivo e um componente comportamental (ROKEACH, 1968 apud PAJARES, 1992, p. 314). Dessa forma, as crenças são opiniões baseadas no conhecimento que se tem sobre determinado assunto, o qual pode ser mais ou menos restrito (PAJARES, 1992, p. 309-313).

Não é raro, por exemplo, que profissionais da educação sugiram aos pais, quando a língua do lar difere da língua majoritária local, que a deixem de falar com a criança, para que esta possa ter sucesso escolar e se integrar mais facilmente, como pudemos observar no testemunho de alguns participantes da pesquisa. Entretanto, tal postura não leva em consideração o prejuízo que a "subtração" pode causar no âmbito identitário e afetivo (BAKER, 2014, p. 141). No caso de imigrantes e refugiados, existe um movimento político maior, 
ilustrado no recorrente desejo do país "anfitrião" de que os estrangeiros se integrem com rapidez e que a língua trazida da família não os "prejudique" na tarefa de aprender a língua nacional.

Para um estrangeiro, em uma sociedade que não é a sua, a língua desempenha, além disso, uma função dual muito clara: ela pode agir como o ponto crucial do processo de integração daquele indivíduo nesta sociedade, através da tentativa por parte dele de aprender a nova língua e falá-la satisfatoriamente no que diz respeito à comunicação; todavia, o fator linguístico pode afastar ainda mais as realidades já distintas, servindo como ponto de atrito, causador de dificuldades, e consequentemente, como fator de exclusão (PUPP SPINASSÉ, 2008, p. 126).

Para Lico (2011, p. 26), o imigrante geralmente deseja que os filhos tenham vínculos afetivos com a família e o país de origem, mas quer também que eles possam viver emoções e situações diversas na língua do país natal. Entretanto, a autora menciona os casos, bastante comuns, de crianças que não entendem por que devem falar a língua dos pais, estando em uma sociedade na qual essa variedade não costuma ser falada. Nesse momento, a família acaba estabelecendo práticas linguísticas que podem fomentar o bilinguismo das crianças, ou podem levar os filhos a abandonar a língua de herança (SAVEDRA; PUPP SPINASSÉ, no prelo).

Vemos aqui que não é apenas o status de cada língua no ambiente social que explica as decisões tomadas dentro da família quando se trata de escolher as línguas a serem passadas aos filhos. Há mais elementos nessas escolhas (DEPREZ; VARRO; COLLET, 2014, p. 10). Para Fogle e King (2013, p. 2), a política linguística familiar é necessária, embora não suficiente para desenvolver o bilinguismo infantil. A aceitação da criança perante a língua depende diretamente dos contextos culturalmente sensíveis e da compreensão de que ela terá padrões de comportamento diferentes dentro e fora de casa.

Dessa maneira, a política familiar tem consequências no sucesso escolar, na manutenção da língua, no domínio da língua minoritária, na relação com a língua (de um) dos pais, na valoração da língua de prestígio social falada por um dos pais, bem como nos processos de aprendizado e de construção identitária. A política linguística familiar é um processo 
construído como as relações entre os membros da família, não havendo nada pronto a priori (FOGLE; KING, 2013, p. 21).

Dessa forma, se a família, por exemplo, acreditar que o plurilinguismo possa trazer prejuízos, não querendo atrapalhar o desenvolvimento (linguístico, escolar e social) da criança, ela justamente acaba por retirar de seu repertório linguístico-cultural elementos fundamentais para esse processo (MOZZILLO, 2015, p. 156).

\section{Ideologias linguísticas}

Considerando ideologia um sistema cognitivo que normaliza e naturaliza a interpretação de experiências, concluise que o senso comum advém das percepções normais que um dado grupo tem do mundo como sistema, das atividades naturalizadas que servem de suporte às relações sociais desse grupo e das estruturas e padrões de poder, as quais, por sua vez, reforçam esse senso comum (DEL VALLE, 2007, p. 15).

Assim como a ideologia remete a sistemas de crenças, ideias e representações subjetivas, também o faz ao âmbito das práticas, como constituinte da construção social dos significados por intermédio das atividades humanas (ARNOUX; DEL VALLE, 2010, p. 9). Portanto, questões como poder, autoridade e legitimidade são centrais para que a língua seja um elemento de ação política, um fenômeno ideológico discursivo, dentro e fora do contexto familiar.

As ideologias linguísticas são, portanto, representações da interseção entre a linguagem e a dimensão social da atividade humana e da carga de interesses morais e políticos nelas inscritos. Não representam apenas a linguagem, mas os elos com as noções de identidade e comunidade, nação e estado, moralidade e epistemologia. Imbricam-se nas estruturas sociais e nos exercícios de poder, o que faz delas um instrumento para a interação verbal, bem como para a ação política e para a imposição, o fortalecimento e a disputa das hierarquias sociais (WOOLARD, 2007, p. 80).

No estudo sobre ideologias linguísticas, que englobam as crenças e os sentimentos sobre as línguas, Kroskrity (2004, p. 10) diferencia a consciência discursiva da consciência prática. A consciência discursiva é uma forma de monitoramento reflexivo que permite aos falantes discutir explicitamente as 
${ }^{3}$ ANGENOT, Marc.

La parole pamphlétaire. Contribution à la

typologie des discours modernes. Paris: Payot, 1982. ideologias. Por sua vez, a consciência prática representa as ideologias presentes em condutas automáticas, as quais são consideradas "certas" e representam o conhecimento não dito. Para o autor, há, por um lado, uma correlação entre uma consciência discursiva forte e a contestação de ideologias e, por outro lado, existe uma correlação entre a consciência prática e a existência de ideologias dominantes altamente naturalizadas, não criticadas.

Nesse sentido, cabe refletir, portanto, sobre as ideologias que levam famílias a optar ou não por bilinguar suas crianças. Conforme a Unesco (2003, p. 15), deve-se dar às crianças a possibilidade de dominar a(s) língua(s) de seus pais e de ter sua própria cultura, em razão de ela ser não apenas um instrumento de comunicação, mas um atributo fundamental da identidade e da realização do potencial do indivíduo e das coletividades. Assim, ao se optar por não transmitir a língua para os filhos, os pais estariam retirando deles direitos linguísticos dos quais toda pessoa deveria poder gozar.

Essa postura dos pais, baseada em suas crenças, desvela certos "motes", manifestações verbais de uma determinada ideologia ou cultura. Arnoux e del Valle (2010, p. 11) utilizam o termo "ideologema", cunhado por Angenot ${ }^{3}$ em 1982, para se referirem a esses lugares-comuns, máximas, postulados que atuam como pressupostos no discurso. Cada época tem um conjunto de ideologemas dominantes produzidas e difundidas nos grupos sociais e nos quais as ideologias linguísticas se apoiam. Essas manifestações léxico-semânticas têm implicações sociais e históricas e são imbuídas de valores culturais (MARTÍN; ALÉS, 2010).

Novos ideologemas vão aparecendo e se impondo quando aquilo que enunciam já está naturalizado na sociedade, nas instituições, escolas e famílias. Com isso, eles vão sendo cada vez menos analisados criticamente ou problematizados, pois se tornam "senso comum". Um exemplo de ideologema corrente no Brasil e que fortalece o mito do monolinguismo nacional seria, por exemplo, que "cada país tem apenas uma língua".

Neste artigo, usaremos a noção de ideologia aqui disposta, representando o conjunto de crenças e atitudes, e nos utilizaremos também desse formato de ideologemas, a fim de ilustrar, com eles, as máximas percebidas por meio das respostas de nossos participantes. 


\section{Metodologia da pesquisa}

Como as práticas familiares dependem das ideologias linguísticas compartilhadas pelos membros, foi nosso objetivo, com a pesquisa aqui apresentada, coletar dados sobre a organização linguística de famílias em situação plurilíngue, em especial sobre a transmissão ou não aos filhos de uma ou mais línguas presentes em casa e/ou na comunidade.

Para tanto, realizamos uma pesquisa de caráter primordialmente qualitativo, utilizando, como instrumento de coleta, questionários enviados a pais e mães de famílias em que coexistem mais de uma língua. Os participantes foram selecionados por meio do método "bola de neve" (BALDIN; MUNHOZ, 2011, p. 331): primeiramente, foram convidadas pessoas do círculo de conhecidos das pesquisadoras, que se encaixassem no perfil de situação plurilíngue, e, a partir daí, esses participantes indicaram outros que também correspondessem ao perfil desejado, e assim sucessivamente. Os questionários foram enviados e retornados preenchidos via e-mail.

O questionário, que se encontra anexado a este trabalho, foi composto por perguntas fechadas, com respostas "sim" ou "não", e por perguntas abertas, para que os participantes pudessem explicar suas escolhas e motivações. Os dados gerados trouxeram informações sobre suas histórias linguísticas, permitindo identificar ideologias linguísticas e analisar suas consequências nos diferentes discursos de participantes que optaram ou não por bilinguar seus filhos.

Recebemos 42 questionários, respondidos em português ou em espanhol, sendo 10 de participantes homens e 32 de mulheres. No conjunto de todas as respostas, foram citadas 15 línguas como constituintes da situação plurilíngue das diferentes famílias representadas na pesquisa: português, alemão standard, árabe libanês, croata, espanhol, estoniano, francês, hindi, hunsriqueano, iídiche, inglês, italiano, polonês, pomerano e russo.

Pensando nas três categorias de famílias em situação plurilíngue listadas na introdução deste artigo, podemos classificar 28 dos participantes como pertencentes a famílias cujos membros possuem línguas maternas distintas, utilizando-as, de alguma forma, no âmbito familiar; seis 
${ }^{4}$ Todas as respostas estão transcritas na sua forma original, sem alterações. Todas as traduções das respostas dadas em espanhol são nossas. participantes estariam inseridos em famílias nas quais a mesma língua é falada, mas cuja mobilidade internacional (mudança de território) as levou à situação plurilíngue; e outros oito participantes, saindo ou não de seus territórios e compartilhando ou não a mesma língua com seu cônjuge, utilizam, no lar, uma língua diferente da(s) sua(s) língua(s) materna(s) e da(s) praticada(s) no entorno.

Dos 36 casos contabilizados de famílias com filhos, em 27 deles (ou seja, 75 \%) houve relato de transmissão linguística intergeracional - em nove deles $(25 \%)$, portanto, as crianças não foram bilinguadas.

\section{Análise dos dados}

Para este artigo, optamos por apresentar a análise de respostas que foram dadas a nove perguntas do questionário $(3,11$ a 17 e 27). Apresentamos o que foi escrito pelos participantes $^{4}$ e, em seguida, listamos os ideologemas bem marcados extraídos dessas falas.

Por meio da pergunta número 3 (Consideras que essas línguas que te rodeavam na tua infância são tuas línguas maternas? Por quê?), buscávamos levantar dados tanto a respeito da noção que os participantes possuem em torno do conceito Língua Materna (doravante LM), quanto sobre aspectos afetivos que poderiam aparecer ao relatarem seus históricos linguísticos mais remotos.

No excerto (1), por exemplo, após informar que falava português e espanhol na infância, a participante afirmou que ambas são suas línguas maternas, dando a seguinte justificativa para tal:

1. Meus pais são de nacionalidades diferentes e cada um utilizava sua língua com seus próprios pais e irmãos. Sim, tenho as duas internalizadas, não faço "tradução" de nenhuma delas e acredito que domino ambas da mesma forma.

Outras respostas semelhantes fornecidas foram as seguintes:

2. Sim, espanhol e português, porque nasci na Argentina, filha de brasileiros. Sempre falava português com os 
${ }^{5}$ Sim, castelhano e inglês. Vivíamos em Singapura onde se fala inglês, mas eu falava castelhano com a minha família. Falava castelhano em casa e inglês na rua. Cresci falando os dois idiomas ao mesmo tempo. Quando tinha quatro anos, nos mudamos para Singapura e só se falava inglês no colégio. meus pais em qualquer ambiente e circunstância, e espanhol no mundo externo.

3. Sim, a língua portuguesa, falada no Brasil, e a língua inglesa, porque era a língua nativa dos meus pais. A língua inglesa era falada pelos meus pais em casa desde que nasci e a língua portuguesa também, falada pelos meus dois irmãos mais velhos concomitantemente em casa.

4. Sí, castellano e inglés. Vivíamos en Singapur donde se hablaba inglés, pero hablaba en castellano con mi familia. Hablaba castellano en casa e inglés en la calle. Crecí hablando los dos idiomas al mismo tiempo. Cuando tenía cuatro años, nos mudamos a Singapur y sólo se hablaba inglés en el colegio. ${ }^{5}$

5. Sim, português e pomerano. A língua mais presente era o pomerano, mas havia também o português, principalmente quando era necessário se deslocar para a cidade. Na escola, o português passou a se tornar mais presente, por ser a língua de escolarização. Pomerano não era a língua do mundo exterior, no caso, fora dos limites da comunidade local. Aprendi as duas línguas de forma natural e paralela. Não sei definir qual possivelmente aprendi primeiro. Aprendi o português paralelamente ao pomerano.

6. Sim, francês e português. Mãe francesa e pai brasileiro, estudava na escola francesa. Falei as duas desde o início.

7. Tinha só português até minha mãe voltar a trabalhar - meus pais contrataram uma babá inglesa que falava em inglês comigo e a minha irmã em casa. Eu tinha 6 anos. Só português até 2001 - meus dois pais são brasileiros, mas eu nasci e cresci em Londres. $\mathrm{O}$ português foi minha primeira língua e falo muito até hoje com os meus pais, meus avós. Volto muito ao Brasil apesar de morar em Londres. Mas o inglês também considero minha língua materna porque fui 
alfabetizada em inglês, é a língua do meu dia a dia, dos amigos.

8. Considero o inglês e o espanhol como minhas línguas maternas porque me desenvolvi e cresci com elas toda a minha infância. Elas eram necessárias para ser capaz de me desenvolver em todos os atos da minha vida diária. Elas são as duas línguas em que eu sinto que me comunico e entendo instintivamente, sem ter que pensar.

É bastante interessante perceber que a noção de língua materna externada pelos participantes da pesquisa é bem mais abrangente do que a noção - geralmente presente no senso comum no Brasil - de que LM seria apenas uma, ou que seria somente a primeira (cronologicamente falando). Percebemos que vários fatores diferentes foram usados para essa caracterização, o que remete a uma forte consciência do que uma língua representa e de que funções ela pode desempenhar.

Com base nas respostas dadas, elaboramos os seguintes ideologemas que fundamentam as ideologias linguísticas relativas ao que é uma LM, ao que seja ter mais de uma língua materna e/ou à maneira como foram adquiridas:

- Ser filho de pais com línguas diferentes.

- Uma língua vir da família e a outra ser a língua do país.

- Ter as duas línguas internalizadas.

- Dominar ambas da mesma forma.

- Ter idiomas que surgem naturalmente quando se expressam as emoções.

- Crescer falando as duas línguas ao mesmo tempo.

- Crescer aprendendo, desde pequeno, as duas línguas.

- Ter uma língua da cidade e outra da comunidade/ família.

- Ter uma língua da escola e outra da comunidade/ família.

- Aprender duas línguas simultaneamente.

- Ter tido uma babá falante de outra língua durante a infância. 
${ }^{6}$ Não é minha língua materna porque a aprendi formalmente depois.
- Ser alfabetizado no exterior.

- Ser alfabetizado no próprio país, mas em língua diferente da familiar.

- As línguas serem familiares e terem marcado a infância.

- Não saber como foram aprendidas.

- Desenvolver-se e crescer com as línguas durante toda a infância.

- Ter duas línguas necessárias aos atos da vida diária na infância.

- Comunicar-se e entender de maneira instintiva.

- Não ter que pensar para falá-las.

- Crescer com elas e conhecê-las melhor do que as aprendidas depois.

Entretanto, houve também - em número bastante inferior - participantes que declararam que as línguas que os cercavam na infância não eram/são LM.

9. No es mi lengua materna porque la aprendí formalmente después. ${ }^{6}$

10. Alemão eu apenas ouvia quando minha avó estava na minha casa.

Podemos perceber, no excerto (9), que a questão cronológica (ou seja, o fato de ser um aprendizado mais tardio) e a questão do tipo de aquisição (o fato de ter sido por meio de instrução formal) fazem essa participante uruguaia, que vive no Brasil, considerar o português uma língua não materna. Já no caso do trecho (10), o critério utilizado para classificar a língua como não materna foi a falta de interação ativa na mesma. $\mathrm{O}$ alemão não era falado pela participante, mas apenas ouvido em seu entorno, quando havia visita da avó.

Essas afirmações nos levaram aos seguintes ideologemas sobre o que não é uma LM:

- Aprender a língua depois de certa idade.

- Aprender a língua formalmente no novo país.

- Apenas ouvir em casa não faz da língua uma LM. 
Também aqui, diferentes critérios e até mesmo uma combinação de critérios são utilizados para classificar a língua não materna, o que demonstra bastante clareza dessas participantes em relação à noção de língua materna defendida por estudos científicos.

Sabemos que uma língua materna não precisa ser a da mãe, nem a do pai, nem a da família, nem a do lugar onde se mora, nem a da comunidade étnica, nem a primeira com a qual se tem contato.

De forma geral [...], a caracterização de uma Língua Materna como tal só se dá se combinarmos vários fatores e todos eles forem levados em consideração: a língua da mãe, a língua do pai, a língua dos outros familiares, a língua da comunidade, a língua adquirida por primeiro, a língua com a qual se estabelece uma relação afetiva, a língua do dia a dia, a língua predominante na sociedade, a de melhor status para o indivíduo, a que ele melhor domina, língua com a qual ele se sente mais à vontade... Todos esses são aspectos decisivos para definir uma L1 como tal (PUPP SPINASSÉ, 2006, p. 5).

Sabemos ainda que milhões de pessoas têm mais de uma língua materna e que elas podem ser adquiridas de forma simultânea ou sucessiva, com a exigência de que ocorra durante a infância, em situação natural e com contato por período prolongado com os falantes.

O bilíngue precoce simultâneo adquire duas (ou mais) línguas, tanto por exposição a ambas desde o nascimento (no caso de casais mistos, por exemplo), quanto por exposição a uma língua após a outra antes dos três anos, aproximadamente. O resultado mais comum é o de equilinguismo ou bilinguismo equilibrado, situação em que se passa por nativo de ambas (MOZZILLO, 2001, p. 293).

Há também o bilíngue precoce sucessivo, no caso de uma das línguas ser adquirida em contexto natural entre os três e os dez anos, aproximadamente. $\mathrm{O}$ resultado mais provável é também o bilinguismo equilibrado, se houver contato prolongado com os falantes. Exemplo típico é a criança de uma comunidade de língua minoritária que adquire a língua majoritária na escola por volta dos seis ou sete anos e se desempenha em ambas como sendo suas LM (MOZZILLO, 2001, p. 293). 
${ }^{7}$ É importante ressaltar que com o uso do termo "nativo" não queremos remeter à ideia de "falante ideal" da Teoria Gerativa. Apenas estamos apontando para o tipo de domínio que se costuma atribuir ao falante quando ele é capaz de gerenciar uma língua como uma língua materna, independentemente de seus domínios, suas funções ou da quantidade de uso, de acordo com as definições de bilinguismo e língua materna apresentados neste artigo.
Além disso, há casos de bilíngues adolescentes que adquirem uma das línguas entre os dez e os 17 anos, aproximadamente, em situação natural, com longa exposição, o que pode ocasionar um bilinguismo equilibrado, embora nem sempre. É o caso de púberes ou adolescentes que se mudam para lugares onde se fala outra língua nesse período da vida e que, por estarem inseridos no ambiente escolar e no contexto natural de aprendizagem de línguas, a adquirem "como nativos"7 $^{\prime \prime}$ ou quase (MOZZILLO, 2001, p. 293). Vale ressaltar que, nesses casos, inclusive fatores afetivos vão influenciar fortemente, refletindo a situação pessoal do indivíduo e sua ligação com o novo país de forma incisiva na relação com a nova língua e no processo de sua aquisição (PUPP SPINASSÉ, 2017, p. 227-228).

No que diz respeito às perguntas de 11 a 17, todas abordaram questões relativas à(s) língua(s) que o respondente transmitiu ao(s) filho(s) e/ou à(s) filha(s): Foi só uma? Qual foi? Por quê? De que contexto ela vem? O que ela representa para o falante? Queríamos ver a relação do falante com a língua, para observar as possíveis ideologias incutidas na decisão de transmiti-la.

Em cerca de $64,6 \%$ dos casos reportados pelos participantes, a LM (ou pelo menos uma das LM) foi transmitida de forma intergeracional. Destes, $80 \%$ vivem em uma localidade onde tal língua não é falada como língua nacional, estando em contato com outra língua na sociedade em que circula - uma situação plurilíngue. Com base nas respostas, pudemos perceber que a grande preocupação dos pais consistiu em transmitir para os filhos sua língua materna, fosse para dar a chance à criança de conhecer sua língua (da mãe/do pai), fosse para manter o vínculo da criança com membros da família no país de origem, fosse para manter o vínculo da criança também com o país de origem, a fim de transmitir um pouco da identidade daquela nacionalidade, fosse para poder continuar falando sua língua sem restrições. Temos que ter em mente que, em muitos casos, falar a língua materna com os filhos foi a única opção, já que não se tinha muita proficiência no outro idioma.

Seja para trazer uma vantagem para os filhos, seja por comodidade própria, vemos, pelas respostas, que transmitir "sua língua" para a criança é a decisão "mais lógica", "mais 
natural" ou "mais espontânea" para esses participantes, conforme os trechos reproduzidos a seguir:

11. Nunca pensei em me comunicar com os meus filhos em outro idioma. Para mim falar o Português com os meus filhos, na minha família, nunca foi questionado. Mesmo morando no exterior.

12. Moro no Brasil, mas falo espanhol com a minha filha porque é uma das minhas línguas maternas. Como sabia que ela aprenderia português no mundo, resolvi falar a outra língua para que fosse bilíngue equilibrada como eu e para que pudesse dominar duas línguas como nativa.

13. Queria que minhas filhas falassem o português, para se comunicarem com a família e terem acesso à cultura delas. Acho importante elas saberem o português e acho que ajuda no desenvolvimento delas intelectual.

14. Acredito ser a melhor decisão falar com ele em meu idioma nativo/materno.

15. Quanto ao português, foi natural, simplesmente gostaria de falar a minha língua materna com minha filha.

É interessante aparecer nas falas dos participantes também a preocupação com as vantagens que o bilinguismo em si pode trazer, como no excerto 3 . Além disso, podemos notar, com base nesses excertos, que falar a língua materna com a criança é uma opção de falar "a língua que melhor se domina"; ou seja, além da intenção de transmitir uma bagagem linguístico-cultural de herança para os filhos, os pais também querem se sentir à vontade na língua falada e conseguir expressar-se livremente e com qualidade - características que, aparentemente, só a LM teria.

Os ideologemas encontrados são, em grande parte, portanto, ligados à ideia de que é evidente que se deve transmitir a sua LM ao filho, mesmo morando em outro lugar e/ou com um cônjuge estrangeiro. Listamos aqui alguns deles: 
- Falar a LM com os filhos possibilita a comunicação com a família.

- Falar a LM com os filhos permite estar à vontade em casa.

- É impensável não falar a LM com os filhos, mesmo morando no exterior.

- Mesmo não sendo uma decisão consciente, é natural falar a LM com os filhos.

- Falar a LM ocorre pela limitação de se falar a língua do lugar.

- Falar a LM possibilita manter vínculos identitários com o país de origem.

- Falar a LM permite manter vínculos identitários com a família que está longe.

- Falar a LM auxilia a valorizar a diversidade linguística.

- Falar a LM serve para dar acesso aos filhos à cultura de origem.

- Falar a LM ajuda no desenvolvimento intelectual dos filhos.

- Falar a LM é dar aos filhos parte do que são os pais.

- Falar a LM é dar uma oportunidade de aprendizado aos filhos.

- Falar a LM é permitir que o filho seja bilíngue equilibrado, tendo duas línguas que domine como nativo.

Existem, da mesma forma, casos de participantes que, tendo eles mesmos duas LM (uma majoritária e uma minoritária), transmitiram apenas uma delas aos filhos, optando por omitir a minoritária do repertório da criança. Foram cinco casos (dos 15 totais de falantes declaradamente bilíngues precoces, ou seja, 33,3\%) que envolveram uma língua de imigração (italiano, hunsriqueano, polonês) ou uma língua de herança (árabe, inglês) - como exposto nos excertos 16 a 20.

16. Transmiti o português] porque é a língua mais usada na cidade, e o italiano só falo em casa e algumas expressões, [...] ele vai acabar sumindo.

17. Falei inglês com os quatro filhos até o inglês deles ser mais do que o do meu marido, que falava muito pouco inglês. Quando sozinha com eles, eu falava 
inglês, mas eles rapidamente passaram a responder em português. Meu marido não falava inglês. Quando o inglês do meu marido não acompanhava mais e estávamos todos juntos, passei a falar com eles em português.

18. A língua de casa era o dialeto Hunsrückisch, mas transmito aos meus filhos alemão padrão e português.

19. [Falo português com eles] porque onde moro agora não se fala polonês e, na escola, poderia gerar problemas de comunicação aos meus filhos.

20. [Transmito a] língua brasileira, a libanesa é só para algumas coisas, palavras por brincadeira. Não a transmiti por ter tido dificuldade na escola, [por] misturar.

Nesses excertos, podemos ver que as línguas minoritárias (em especial de imigração) parecem ter, aos olhos dos falantes, menos funcionalidade e/ou menos importância do que a majoritária que eles também dominam como LM, ou até mesmo representar dificuldades ou traumas por problemas ou situações de preconceito vividas. Assim, extraímos os seguintes ideologemas sobre o tema:

- Não tem utilidade transmitir uma língua pouco usada fora de casa.

- Não se pode falar uma determinada língua com os filhos se o cônjuge a entende mal.

- Não é útil insistir numa língua quando não a se quer falar.

- Quando se transmite mais de uma língua ao filho, a língua de menos prestígio não é necessária.

- Por não morar mais no local da língua minoritária, a língua é prescindível.

- A língua de imigração/de herança pode gerar problemas escolares aos filhos.

- A língua de herança é transmitida parcialmente, com poucas palavras e para brincar.

- Não se deve transmitir uma língua que não é a majoritária para não haver perigo de misturar. 
Temos, entre os participantes, também aqueles que decidiram não usar sua língua materna com as crianças, utilizando a língua do cônjuge ou a do lugar de moradia. Trata-se de seis dos 36 participantes com filhos (16,7\%), dos quais cinco estão inseridos em um meio no qual sua LM não é falada, abrindo mão, assim, de que os filhos a aprendam, aderindo totalmente à língua local e/ou à do cônjuge (mesmo estando em território onde esta já é falada como majoritária). Em quatro casos, essa decisão levou ao monolinguismo das crianças, que realmente só tiveram acesso à língua local; em dois, porém, as crianças, mesmo assim, foram bilinguadas, já que foram expostas a outras línguas além da adotada em casa. Podemos perceber, portanto, como a configuração do meio influencia a escolha individual/familiar. Ilustramos isso com os trechos reproduzidos a seguir:

21. Por força da qualidade de falante nativa de espanhol da mãe da minha filha, preferi apoiar a escolha de criá-la como bilíngue no Brasil.

22. Acho que a língua do meu marido tem mais status do que a minha [no contexto em que vivemos], daí o motivo de falar com as crianças em francês.

23. Meu português tem muita coisa errada porque não estudei. Prefiro falar espanhol com meu marido argentino e filhos, já que nasceram na Argentina.

24. Falamos exclusivamente em inglês com a nossa filha porque ele é americano e não há dúvida do peso da língua no mundo.

25. Porque nasceram no Brasil e moramos aqui. Português é a língua que eles precisam na escola e para brincar com seus amigos.

${ }^{8}$ Falo português com a minha filha porque vivo aqui e tive medo de confundir a cabeça dela.
26. Hablo portugués con mi hija porque vivo aquí y tuve miedo de confundirle la cabeza. ${ }^{8}$

Assim como no caso das línguas de imigração e de herança citadas nos excertos 16 a 20, também aqui, considerando a fala dos participantes, a decisão pela língua majoritária está atrelada a questões de valor (por conta da acurácia), de status e de prestígio. Em outros termos, apesar de as famílias estarem em situação plurilíngue, não houve a intenção de se bilinguarem os filhos. Apenas no caso do excerto 21, no 
qual o pai brasileiro passou a falar a língua castelhana da esposa (brasileira nascida na Argentina), a decisão foi tomada puramente em prol do bilinguismo da filha.

Os ideologemas identificados nesses testemunhos são:

- O cônjuge ser nativo de outra língua justifica falar nessa língua com o filho.

- Auxiliar a criança a reforçar a língua menos representada no contexto justifica o uso da língua não materna.

- Se a língua do cônjuge tem mais prestígio, não se precisa transmitir a outra.

- O cônjuge ser americano define a escolha de falar a "língua franca" inglês com a criança.

- O peso da língua no mundo autoriza a usar uma língua não materna com os filhos.

- A LM não deve ser transmitida quando é "errada", sem instrução escolar.

- Deve-se falar a língua local com os filhos, para ajudar na escola, para ajudar na socialização com as outras crianças locais.

- Falar a língua do lugar impede confusões na cabeça da criança.

Ainda no grupo de participantes que falam uma língua não materna com os filhos, há aqueles que fizeram essa opção para usar uma terceira língua, não materna de nenhum dos dois membros do casal e nem presente no entorno. Essa configuração linguística familiar, que corresponde a $22,2 \%$ dos casos, é motivada por questões afetivas, psicolinguísticas e/ou por questões políticas, conforme podemos apreender das respostas de 27 a 31, a seguir.

${ }^{9}$ No meu caso, preferi falar com minhas filhas em inglês, porque é o idioma do colégio internacional. Queria que não tivessem os problemas que observei em outras famílias bilíngues: muitas crianças não conseguem manejar nem um idioma nem outro.
27. En mi caso, preferí hablar con mis hijas en inglés, porque es el idioma del colegio internacional. Quería que no tuvieran los problemas que observé en otras familias bilingües: muchos niños no pueden manejarse bien ni en un idioma ni en otro. ${ }^{9}$

28. O inglês por ser o idioma de instrução nas escolas britânicas do Kuwait. A língua inglesa teve de ser adotada, pois eu sempre quis participar da vida 
acadêmica dos meus filhos. No Kuwait não existem escolas de língua portuguesa e as de idioma árabe não oferecem um bom nível de instrução.

29. Porque julguei importante expor meus filhos a duas línguas. Sabia que português aprenderiam com os familiares, então optamos por inserir mais uma. Havia estudado sobre bilinguismo e conhecia os benefícios.

30. Como no meu mundo há muita presença da língua alemã e ela faz parte de mim, para que meu filho me conhecesse $100 \%$ e fizesse parte $100 \%$ do meu mundo, era necessário que ele soubesse alemão.

31. Uma terceira língua, não nativa de nenhum dos pais e nem do lugar, ajuda na união familiar por causa da falta de competência de algum deles na outra língua.

Consideramos relevante comentar ainda que em metade desses casos, devido à opção por transmitirem aos filhos uma língua não materna e não presente no entorno, a(s) língua(s) materna(s) dos pais terminaram não sendo passadas aos filhos. Na outra metade dos casos, apesar da prática adotada, como a língua materna (ou uma das línguas maternas) dos pais está presente no entorno, ela foi adquirida pelas crianças no dia a dia, paralelamente à língua que estava sendo transmitida em casa, como no caso dos pais brasileiros, no Brasil, que falam alemão standard com os filhos.

Os ideologemas percebidos nesses casos foram:

- Falar a língua do colégio internacional evita problemas.

- Crianças bilíngues não manejam bem nenhuma das línguas.

- Usar o inglês facilita a participação na vida escolar dos filhos.

- É relevante inserir uma terceira língua, já que o bilinguismo é benéfico e a língua do lugar será aprendida com os familiares.

- É útil falar com os filhos na língua em que o casal se comunica.

- Uma língua não usada com frequência não precisa ser transmitida na primeira infância. 
${ }^{10}$ Me arrependo de não ter ensinado minha filha a falar os dois idiomas, português e espanhol da mesma forma ou simultaneamente.

${ }^{11}$ Não me arrependo, porque ela pode usar cada uma das línguas (português e espanhol) em contextos específicos. Essa possibilidade no teria sido possível se apenas tivéssemos usado o português em todas as situações.
- É pertinente transmitir ao filho a língua da qual se é professor.

- Transmitir ao filho a língua da qual se é professor permite que ele conheça totalmente o mundo da mãe.

- Falar a língua da escola ajuda a criança a ter a informação correta.

- Falar a língua escolar auxilia a fazer relações com a língua de casa.

- Uma terceira língua é benéfica à união familiar, já que cada um dos pais não domina bem a do outro.

- Falar com o filho uma terceira língua, não materna do pai, é uma vantagem para ele.

Em relação à questão 27 (Te arrependes de teres falado uma determinada língua com o teu filho? Ou de não teres falado? Por quê?), fica claro que alguns se arrependem de não terem falado a sua LM com os filhos e que outros, contrariamente, não se arrependem de terem deixado de transmitir a sua LM.

32. Não me arrependo nem um pouquinho, porque as minhas filhas vivem neste meio, o pai é brasileiro e a gente não fala mais a língua libanesa depois que perdi meus pais.

33. Me arrepiento de no haber enseñado a mi hija hablar los dos idiomas, portugués y español de la misma forma, o simultáneamente. ${ }^{10}$

34. Não me arrependo de não ter persistido, porque todos falaram inglês quando precisaram. E uma falou também espanhol e holandês por causa do trabalho.

35. No me arrepiento porque ella puede utilizar cada una de las lenguas (portugués y español) en contextos específicos. Esta posibilidad no hubiera sido posible si solo hubiésemos utilizado el portugués para todas las situaciones. ${ }^{11}$

36. Nunca me arrependi de ter falado espanhol com a minha filha brasileira para que pudesse ter, como eu, duas línguas maternas. Ela me agradece que falemos em espanhol sempre e aprecia poder se desempenhar como nativa. 
${ }^{12}$ Me arrependo de ter deixado a minha filha me responder em português em vez de ter criado mais incentivos para que falasse espanhol comigo. Não tenho mais filhos, mas, se tiver, falarei espanhol e tentarei que ele responda em espanhol.

${ }^{13}$ Não me arrependo, estou muito feliz de poder falar meus três idiomas principais com eles.
37. Me arrepiento de haber dejado mi hija contestarme en portugués en lugar de haber creado más incentivos para que ella hablara en español conmigo. No tengo más hijos, pero si llego a tener, hablaré en español e intentaré que mi hijo conteste en español. ${ }^{12}$

38. Não me arrependo de ter falado alemão com ele. Faria de novo (tanto que estou fazendo com a menor).

39. Gostaria de ter insistido mais quando tive o segundo filho, com a língua inglesa. Fomos usando cada vez mais o português em casa, já que meu filho se comunicava com a irmã mais nova em português, tal como fizeram meus irmãos mais velhos comigo em casa.

40. Me arrependo de não falar só em francês com a minha filha. Mas eu acabo esquecendo.

41. Não vejo razão para mudar a decisão de não falar minha língua materna com ele. Eu trabalho em inglês, a única vez que uso o alemão é quando falo com os avós, o que não acontece com muita frequência.

42. No me arrepiento, estoy muy feliz de poder hablar mis tres idiomas principales con ellos. ${ }^{13}$

43. Sim, me arrependo de não ter falado em polonês, porque seria bom pra eles saber outra língua além do português.

Com base nas ideologias linguísticas expressas pelos participantes nessas respostas à pergunta 27 , encontramos os seguintes ideologemas ${ }^{14}$ :

${ }^{14}$ Sempre lembrando que os ideologemas aqui expostos não necessariamente correspondem à nossa opinião. Apenas os elaboramos tomando por base as ideologias percebidas nas falas dos participantes.
- Não há motivo para falar uma língua que não é a do lugar onde moram os filhos.

- Não há motivo para falar uma língua que não é a do pai dos filhos.

- Não há motivo para falar uma língua quando os familiares que a falavam já morreram.

- É lamentável não ensinar as duas línguas da mesma forma.

- Transmitir a LM ao filho que está se criando no exterior é apreciado por ele.

- Não exigir que o filho responda na LM do pai é lamentável. 
- É lamentável não insistir mais para que os filhos respondam na outra língua.

- É lamentável esquecer de falar a LM com o filho.

- Não há problema em não falar a LM com o filho.

- É válida a experiência de falar uma língua não materna com o filho.

- É importante que os filhos falem todas as línguas dos pais.

- Não falar uma língua restringe o repertório linguístico da criança.

- Falar mais de uma língua é algo que a criança apreciará.

Em relação a essa pergunta, podemos ver que o não arrependimento se dá tanto por terem falado (como no excerto 35) quanto por não terem falado (como no excerto 34) determinada língua com as crianças, pois os participantes estão pautados em suas crenças para tomarem essas decisões conscientemente e expressarem suas ideologias. Em alguns casos, contudo, mesmo assim a criança pôde crescer bilíngue - em poucos casos o resultado foi o monolinguismo (como nos excertos 32 e 43). Já entre os casos de arrependimento, vemos que a justificativa mais frequente é o lamento pela falta de insistência em manter a prática na sua língua materna com a criança. É interessante perceber, porém, que ninguém disse ter-se arrependido de ter bilinguado os filhos.

\section{Conclusão}

É importante pontuar que, embora tenhamos encontrado algumas crenças negativas relacionadas com o bilinguismo precoce no discurso de pais que deixaram de bilinguar os seus filhos, encontramos uma grande consciência sobre o assunto no discurso dos pais que criaram seus filhos de maneira bilíngue - que somam a maioria. Eles compreendem que a família é o centro da vida infantil e que a base da transmissão e do uso das línguas depende dela.

Os dados de nossa pesquisa nos permitem ver que há nuances nos tipos de situação de bilinguismo elencados por Romaine (1997, p. 183) e citados na segunda seção deste artigo, já que, em qualquer caso, pode haver alternância e/ou 
mistura. No âmbito familiar, os pais definem a dinâmica do plurilinguismo e a sua manutenção, e suas atitudes podem determinar o grau de proficiência linguística das crianças. Conforme a pressão social e as experiências individuais com o seu próprio bilinguismo, haverá maior ou menor sucesso com o bilinguismo familiar.

A criança deve ser o centro da situação linguística quando se quer fazer dela uma pessoa bilíngue. Necessita de contato diário com a língua, não só quando muito pequena, no período de aquisição, mas, prolongadamente, pelo menos até à adolescência, de forma a conseguir desenvolver competências de compreensão e produção em ambas as línguas (FLORES, 2017, p. 248). Para isso, contudo, a família precisa estar empenhada nesse processo.

Por meio de nossos participantes pudemos notar uma tendência positiva para o bilinguismo familiar, já que a maioria das famílias optou por criar crianças bilíngues, acreditando ser esta a melhor opção e esforçando-se para construir políticas linguísticas familiares que fomentem ou deem espaço ao aprendizado de mais línguas.

Entretanto, é fundamental entender que cada família tem suas próprias crenças e normas para falar e agir, não existindo uma receita pronta ou um objetivo único ou ideal a ser alcançado quando se pensa no bilinguismo familiar. Cada família vai determinar o mais adequado para si, já que um bilinguismo exitoso pode não ser necessariamente aquele que as crenças do senso comum determinam.

\section{REFERÊNCIAS}

ARNOUX, Elvira Narvaja de; DEL VALLE, José. Las representaciones ideológicas del lenguaje - Discurso glotopolítico y panhispanismo. Spanish in Context, Amsterdam, v. 7. n. 1, p. 1-24, 2010.

BALDIN, Nelma; MUNHOZ, Elzira. Snowball (bola de neve): uma técnica metodológica para pesquisa em educação ambiental comunitária. In: CONGRESSO NACIONAL DE EDUCAÇÃO, 10, 2011, Curitiba. Anais [...]. Curitiba: PUCPR, 2011. p. 329-341. 
BAKER, Colin. A parents'and teachers' guide to bilingualism. Bristol: Multilingual Matters, 2014.

DEL VALLE, José. Glotopolítica, ideología y discurso: categorías para el estudio del estatus simbólico del español. In: (org.). La lengua, ¿patria común? Ideas e ideologías del español. Madrid/Frankfurt: Iberoamericana/Vervuert, 2007. p. 13-30.

DEPREZ, Christine; VARRO, Gabrielle; COLLET, Beate. Introduction. Familles plurilingues dans le monde. Mixités conjugales et transmission des langues. Langage E société, Paris, n. 147, p. 7-22, $1^{\circ}$ sem., 2014.

ELLIS, Rod. The study of second language acquisition. 2 ed. Oxford: Oxford University Press, 2008.

FLORES, Cristina. Bilinguismo infantil. Um legado valioso do fenómeno migratório. Diacrítica. Volume Temático sobre Imigração, refugiados e as humanidades: abordagens críticas para novos desafios, Braga, n. 31, v. 3, p. 237-250, 2017.

FOGLE, Lyn W.; KING, Kendall A. Child agency and language policy in transnational families. Issues in Applied Linguistics, Los Angeles, v. 19, p. 1-25, 2013.

GROSJEAN, François. Life with two languages. An introduction to bilingualism. Cambridge: Harvard University Press, 1982.

A psycholinguistic approach to code-switching: the recognition of guest words by bilinguals. In: MILROY, Lesley; MUYSKEN, Pieter (ed.). One speaker, two languages. Crossdisciplinary perspectives on code-switching. Cambridge: Cambridge University Press, 1995. p. 259-275.

HAKUTA, Kenji. Mirror of language. The debate on bilingualism. New York: Harper Collins Publishers, 1986.

HAMERS, Josiane; BLANC, Michel. Bilinguality and bilingualism. Cambridge: Cambridge University Press, 1989.

KING, Kendall A.; LOGAN-TERRY, Aubrey. Additive bilingualism through family language policy: strategies, 
identities \& intercultural outcomes. Calidoscópio, São Leopoldo, v. 6, n. 1, p. 5-19, jan./abr. 2008.

KROSKRITY, Paul. Language Ideologies. In: DURANTI, Alessandro (org.). A companion to linguistic anthropology. Oxford: Blackwell, 2004. p. 496-517.

LICO, Ana Lucia Cury. Ensino do português como língua de herança: prática e fundamentos. Revista SIPLE, Brasília, v. 1, n. 2, p. 22-33, maio 2011.

MACKEY, William F. Bilingualism and multilingualism in North America. In: BHATIA, Tej K.; RITCHIE, William C. (org.) The handbook of bilingualism and multilingualism. Oxford: WileyBlackwell, 2013. p. 707-724.

MARTÍN; Carmen Ávila; ALÉS, Francisco Linares. Algunas nociones sociocríticas y la dimensión cultural de las palabras. Sociocriticism, Granada, v. 25, n. 1/2, p. 93-118, 2010.

MOZZILLO, Isabella. A conversação bilíngüe dentro e fora da sala de aula de língua estrangeira. In: HAMMES, Walney; VETROMILLE-CASTRO, Rafael (org.). Transformando a sala de aula, transformando o mundo: ensino e pesquisa em língua estrangeira. Pelotas: Educat, 2001. p. 287-324.

Algumas considerações sobre o bilinguismo infantil. Veredas (on-line), Juiz de Fora, v. 19, n. 1, p. 147-157, 2015.

MOZZILLO, Isabella; PUPP SPINASSÉ, Karen. Políticas linguísticas familiares em contexto de línguas minoritárias. Linguagem \& Ensino, Pelotas, v. 23, n. 4, p.1297-1316, 2020.

OBSERVATÓRIO EUROPEU DO PLURILINGUISMO. Carta informativa $n^{\circ}$ 31. Paris, fev. 2010. Site: Observatoire Plurilinguisme. Disponível em: https:// www.observatoireplurilinguisme.eu/images/Lettre_d_ information/Lettre_31/lettre\%20n\%B031pt.pdf. Acesso em: 24 set. 2020.

OLIVEIRA, Gilvan Müller de. Brasileiro fala português: monolinguismo e preconceito lingüístico. In: SILVA, Fábio Lopes de; Moura, Heronides M. de Melo (org.). O direito à fala: 
A questão do preconceito lingüístico. Florianópolis: Editora Insular, 2002, p. 83-92.

PAJARES, M. Frank. Teachers' beliefs and educational research: Cleaning up a messy construct. Review of Educational Research, Pennsylvania, v. 62, n. 3, p. 307-332, Autumn 1992.

PEARSON, Barbara Zurer. Raising a bilingual child: A step-bystep guide for parents. New York: Random House, 2008.

PEIRCE, Charles Sanders. Selected writings (Values in a universe of change). Edited from Philip P. Wiener. New York : Dover Publications, 1958/1966.

PUPP SPINASSÉ, Karen. Os conceitos Língua Materna, Segunda Língua e Língua Estrangeira e os falantes de línguas alóctones minoritárias no Sul do Brasil. Revista Contingentia, Porto Alegre, v. 1, n. 1, p. 1-10, nov. 2006.

Os imigrantes alemães e seus descendentes no Brasil: a língua como fator identitário e inclusivo. Revista Conexão Letras, Porto Alegre, v. 3, n. 3, p. 125-140, 2008.

Língua materna, língua estrangeira, língua adicional e as suas relações em um contexto multilíngue do Brasil. In: SILVA, Carmem L. da Costa.; DEL RÉ, Alessandra; CAVALCANTE, Marianne C. B. (orgs.). A criança na/com a linguagem: saberes em contraponto. Porto Alegre: Instituto de Letras UFRGS, 2017. p. 223-235.

ROMAINE, Suzanne. Bilingualism. Oxford: Blackwell, 1997.

SAVEDRA, Mônica M. Guimarães; PUPP SPINASSÉ, Karen. $\mathrm{O}$ ensino de variedades germânicas em contextos de contato linguístico: conceitos, princípios e diretrizes. In: KRETSCHMER, Johannes; SAVEDRA, Mônica M. G.; BOLACIO FILHO, Ebal Sant'Anna; FERREIRA, Mergenfel Vaz; LAGES, Susana Kampff (orgs). Travessias, Encontros, Diálogos nos Estudos Germanísticos no Brasil. Niterói: Eduff/ABEG, no prelo.

UNESCO. La educación en un mundo plurilingüe. Paris: Organización de las Naciones Unidas para la Educación, la Ciencia y la Cultura, 2003. 
WOOLARD, Kathryn A. La autoridad lingüística del español y las ideologías de la autenticidad y el anonimato. In: DEL VALLE, José (org.). La lengua, ¿patria común? Ideas e ideologías del español. Madrid/Frankfurt: Iberoamericana/Vervuert, 2007. p. 73-94. 


\section{Anexo}

\section{Questionário completo}

1. Havia mais de uma língua na tua casa durante a tua infância? Quais? Por quê?

2. Havia apenas uma língua na tua casa durante a tua infância, mas que não coincidia com a do mundo exterior? Qual? Por quê?

3. Consideras que essas línguas que te rodeavam na tua infância são tuas línguas maternas? Por quê?

4. A tua família de origem veio de um lugar onde se fala $/ \mathrm{m}$ outra/s língua/s? Em que época?

5. Aprendeste a língua do mundo externo ao teu por teres te mudado? Em que idade? Como foi?

6. Se não és do lugar onde moras, já tinhas a tua família própria (cônjuge e/ou filhos) ou formaste família no novo lugar?

7. Qual é o teu histórico linguístico? Que línguas aprendeste mais adiante de forma natural? (em contato com nativos, no lugar onde elas eram faladas naturalmente). E quais de forma artificial (em cursos de línguas, escola)?

8. Qual a ordem de aprendizado de todas as línguas com as quais tiveste contato?

9. Em que nível consideras que as dominas? E em quais habilidades (ler, falar, entender, escrever)?

10. O desempenho em cada uma delas foi sempre o mesmo ou em alguma/s houve retrocesso em relação a outras aprendidas depois?

11. Que língua transmites ao teu filho?

12. É mais de uma?

13. É uma língua materna tua?

14. É a língua do teu local de origem?

15. É a da tua família de origem?

16. É outra na qual não te desempenhas como nativo?

17. Como e por que tomaste essa decisão?

18. O teu cônjuge te apoiou? De que forma?

19. Ele compartilha das tuas línguas? De quais? Em que nível? 
20. Teu cônjuge e tu falam em que língua/s entre si? É sempre a mesma? Em que circunstâncias?

21. É/São a/s mesma/s usadas com o teu filho? Por quê? É língua materna dele?

22. O status que a/s tua/s língua/s tem/têm na sociedade influenciou a tua decisão? De que forma?

23. Sofres algum preconceito por usares alguma língua em particular? Por parte de quem? Em que situação?

24. Terias preferido não ser falante de mais de uma língua? Por quê?

25. Acreditas que é prejudicial à criança falar mais de uma língua na idade escolar? Por quê?

26. Os teus professores e/ou os do teu filho demonstram/ demonstraram contrariedade ou temor pelo fato de falares/falarem mais de uma língua?

27. Te arrependes de teres falado uma determinada língua com o teu filho? Ou de não teres falado? Por quê?

28. Com o teu segundo filho/próximo filho tomarás a mesma decisão? Por quê?

29. Se a língua na qual falas em casa com o teu cônjuge e/ou com o teu filho não é tua língua materna, sentes alguma dificuldade? Qual?

30. O que pensas da alternância de uma língua para a outra durante a conversa ou conforme a situação comunicativa? Por quê?

31. Em que medida o teu cônjuge e os teus filhos compartilham as línguas que fazem parte do teu histórico linguístico? (Seja porque eles usam essas línguas em casa, seja porque eles as aprenderam em outras situações)

32. E o que eles acham sobre o próprio desempenho em cada uma delas?

33. Concordas com a ideia que eles têm sobre como dominam cada língua? Por quê?

34. O que pensam os membros da tua família sobre o teu desempenho em cada uma das línguas que usas?

35. Concordas com a ideia que eles têm sobre o teu domínio de cada idioma? Por quê?

36. Gostarias de comentar algo que não foi perguntado?

37. Ou de fazer uma pergunta sobre o assunto? 


\section{ABSTRACT}

Families in Multilingual Situation:

\section{Linguistic Ideologies}

Linguistically mixed families have a tacit or explicit agreement, which constitutes the family linguistic policy (KING; LOGAN-TERRY, 2008; MOZZILLO; PUPP SPINASSÉ, 2020) and which defines the daily practices, as well as the project of transmission and maintenance (or not) of the languages. When the home language(s) do(es) not coincide with that/ those of the external environment, there can be a situation of confrontation between what is minority and what is majority. The way the family will deal with plurilingualism is a choice often not necessarily based on a conscious or enlightened decision, but it is largely influenced by linguistic ideologies (WOOLARD, 2007) - which are not always in accordance with the results of studies in the area, since these ideologies are constantly imbued with beliefs (PAJARES, 1992). Thus, depending on the practices adopted, the family can determine and foster the bilingualism of their children, or even prevent them from being raised with more than one language, leading to monolingualism. In this sense, this article intends to approach some linguistic ideologies obtained from the discourse of fathers and mothers of families in a plurilingual situation, presenting the ideologemes found.

Keywords: Linguistic Ideologies.

Multilingual families. Family bilingualism.

Isabella Mozzillo é Professora Titular do Centro de Letras e Comunicação, atuando com Língua Francesa, Linguística Aplicada, Línguas em contato e Políticas linguísticas.

Karen Pupp Spinassé é Professora Associada do Departamento de Línguas Modernas do Instituto de Letras, atuando nas linhas de Linguística Aplicada e de Sociolinguística com os temas $\mathrm{Bi} /$ Plurilinguismo, Biletramento, Didática do Multilinguismo, Políticas linguísticas e Língua Alemã. 